\title{
K-RAS GLY-12 Mutant Protein
}

National Cancer Institute

\section{Source}

National Cancer Institute. K-RAS GLY-12 Mutant Protein. NCI Thesaurus. Code C29137.

A synthetic form of the K-ras protein containing any one of a number of point mutations at position 12 which is normally occupied by glycine (GLY). Vaccines using mutant K-ras proteins may be used in the immunotherapy of various cancers that express mutated Kras proteins. $(\mathrm{NClO4})$ 